\title{
Alterations in malondialdehyde levels and superoxide dismutase activity in the sera of occupational workers in Erbil city
}

\begin{tabular}{cccc}
\hline Gaylany H Abdullah $*$ & Sardar N Ahmed $* *$ & Nadir M Nanakali $* * *$ & Abdul-Qadir A Hassan $* * * *$ \\
\hline Abstract
\end{tabular}

Background and objective: Malondialdehyde is the end product of lipid peroxidation by oxidative stress (free radicals). Superoxide dismutase is one of the important antioxidant enzymes that catalyze conversion of superoxide to hydrogen peroxide. The aim of present study is to measure the serum Malondialdehyde concentration and Superoxide dismutase activity in occupational workers.

Methods: A prospective study was carried out from October 2011 to May 2012 in collaboration between clinical biochemistry department at the College of Medicine-Hawler Medical University and chemistry department at the faculty of science and health at Koya University. Total of thirty non-office occupational workers were targeted, who exposed to air and industrial material pollutions, all individuals were healthy and non-alcoholics.

Results: The mean value of each of the serum Malondialdehyde concentration and serum Superoxide dismutase activity were significantly higher in occupational workers than that of non-occupational workers.

Conclusion: Based on findings of the present study it can be concluded that occupational works elevates the release of Superoxide dismutase enzyme, and also increases lipid peroxidation by reactive oxygen species which in turn causes elevation of Malondialdehyde.

Keywords: Serum Super oxide dismutase (SOD), serum malondialdehyde (MDA), oxidative stress, occupational works.

\section{Introduction}

Free radicals are unstable compounds with an unpaired electron in outer shell. Normally all aerobic cells form unwanted byproducts of normal metabolism reactive oxygen radicals (ROS). These are free radicals containing oxygen atom. They formed during the process of respiration, phagocytes, arachidonic acid metabolism and other ordinary processes while metabolizing oxygen. Free radicals are also formed when hard radiation impacts living system. Pollution, cigarette smoke are also forming free radicals in the living organisms. These free radicals are quickly detoxified by antioxidant systems. If the formation of free radicals comes to a rate that exceeds the capacity of the antioxidant system in the cell, the free radicals formed may damage basic molecules such as lipids, proteins, carbohydrates and nucleic acids ${ }^{1}$. The most ROS including hydroxyl radicals $(\mathrm{OH})$, superoxide anions $\left(\mathrm{O}_{2}{ }^{\cdot-}\right)$ and hydrogen peroxide $\left(\mathrm{H}_{2} \mathrm{O}_{2}\right)$, they are generated in response to external and internal stimuli ${ }^{2}$.Low levels of ROS are necessary for several biological processes including intracellular differentiation and cell progression or arrest of apoptosis growth, immunity, and defense against microorganisms. In contrast, high doses and/or inadequate removal of ROS result in oxidative stress which may cause damage to biological macromolecules ${ }^{3}$. Uncontrolled lipid (ROS) causes DNA damage in living organisms by a variety of mechanisms. The highly reactive hydroxyl radical reacts with the heterocyclic DNA

* Department of Chemistry, Faculty of Science and Health, Koya University, Kurdistan Region, Iraq.

** Department of Medical Biochemistry, College of Medicine, Hawler Medical University, Erbil, Iraq.

*** Department of Biology, College of Education - Scientific Departments, Salahaddin University, Erbil, Iraq $* * * *$ Department of Inspection and Proceedings, Erbil Directorate of Health, Ministry of Health, Erbil, Iraq. 
bases and the sugar moiety near or at diffusion-controlled rates ${ }^{4}$. Production can cause cell injury and death via DNA damage and directly inhibiting proteins, such as $\mathrm{Na}^{+} / \mathrm{K}$-ATPases and glutamate transporters ${ }^{5}$. The protecting feature of Superoxide dismutase (SOD), one of the antioxidant enzymes against oxidative stress bears an essential role for life $^{6}$. Oxidative stress has long been suspected to be involved in many disease processes including carcinogenesis, neurodegeneration, diabetes mellitus, and aging. Reactive degrade polyunsaturated lipids forming malondialdehyde ${ }^{7,8}$. This compound is a reactive aldehyde and is one of the many reactive electrophile species that cause toxic stress in cells and form covalent protein adducts. The production of this aldehyde is used as a biomarker to measure the level of oxidative stress in an organism $^{9}$. The plasma concentration of Malondialdehyde (MDA) is the most frequently used biomarker providing an indication of the overall lipid peroxidation caused by many diseases ${ }^{10,11}$. Superoxide dismutase (SOD) is an enzyme that repairs cells and reduces the damage done to them by superoxide. SOD enzymes were previously thought to be several metalloproteins ${ }^{12-14}$ with unknown function, for instance, CuZnSOD were known as erythrocuprein. SOD also helps the body to utilize zinc, copper, and manganese. There are two different forms of this enzyme. These two enzymes work in different compartments of the cell, and they utilize different positively charged metal ions to neutralize the negatively charged superoxide radicals. Each type of SOD plays a different role in keeping cells healthy ${ }^{15}$. $\mathrm{Cu} / \mathrm{Zn}$ SOD is activated by the delivery of copper by the human metallochaperone $\mathrm{CCS}^{16}$ protects the cells' cytoplasm ${ }^{15}$ and Mn SOD protects their mitochondria ${ }^{17}$. The majority of oxygen metabolism and respiration processes take place in mitochondria, many oxygen radicals are therefore generated in this compartment. Unfortunately, human's body production of SOD peaks as early as the age of 10 , after which that the levels begin to decline by about 15 per cent per decade. Although SOD is also present in certain foods including cabbage, broccoli, wheat and barley grasses, it is difficult to boost their levels through diet alone $^{18,19}$. Free radicals emerge not only during normal oxygen metabolism and inflammatory processes, but also as a consequence of exposure to ionizing radiation, cigarette smoke or excessive alcohol consumption. Cellular free radicals target key organic substrates such as lipids, DNA and proteins. Protective agents and defense mechanisms act to minimize oxidative damage. This antioxidant system consists of (1) small molecules such as vitamin $C$ and $E$, glutathione, carotenes and coenzyme $Q$, as well as (2) enzyme antioxidants which detoxify radicals or repair oxidized molecules. In aging cells and organisms and under certain pathophysiological conditions - such as smokers' emphysema, rheumatoid arthritis, Alzheimer's and Parkinson's disease accumulation of biomolecule oxidation products indicate a disturbed balance in the oxidative stress response $e^{20-22}$. This study is thus aimed to estimate both the serum MDA and SOD in different types of no-office occupational workers to evaluate the effect of accupational works on ROS production.

\section{Methods}

\section{A-Separation of serum:}

Five $\mathrm{ml}$ of blood from the vein of sample persons were taken transferred into test tubes then kept aside for about half an hour. Sample bloods were centrifuged at $3000 \mathrm{rpm}$ for 10 minutes. Serum was separated from the RBC and other precipitants using a proper micro-pipette and transferred to a new tube and kept in the refrigerator until it was used.

\section{B-Sampling:}

Total of thirty non-office occupational workers were targeted, all individuals were healthy and non-alcoholics. Six of them were traffic policemen who spent at least 
two years serving on the streets. Six of them were dyers who spent no less than two years dying cars using spraying-guns and polishing materials. The same number of individuals was working in oil refinery field. Twelve of them were industrial estate welding workers who have worked regularly with welding.

\section{C- Methods}

\section{Determination of serum MDA}

Lipid peroxidation was estimated according to the method described by Rehncrona et al 23 Measurement of (MDA), a secondary product of lipid peroxidation was based on the colorimetric reaction with thiobarbituric acid 20 which is based on the reaction of (MDA) with thiobarbituric acid (TBA) forming red, fluorescent MDA-TBA2 adduct21 that absorbs strongly at wavelength 532 $\mathrm{nm}$, Figure $1^{24}$.

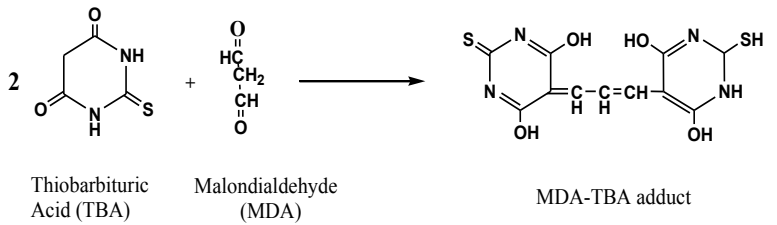

Figure 1: Formation MDA: $(\text { TBA })_{2}$ adduct.

2. Evaluation the activity of SOD using modified photochemical Nitroblue Tetrazolium (NBT) method. This method includes the use of sodium cyanide as peroxidase inhibitor, and also used to determine the activity of superoxide dismutase by indirect method via the change in the color intensity of formazin which produced by the reduction of $\mathrm{O}_{2}$ in nitroblue tetrazloium dye. Decrease in the optical density of formazin is the indication of increase in the effectiveness of the enzyme (SOD). The reaction mixture in one centimeter cuvette was radiated by using the fluorescent lamp of 20 watt for 10 minutes at $25{ }^{\circ} \mathrm{C}$. Then the absorbance at $560 \mathrm{~nm}$ was measured. The activity of superoxide dismutase was calculated by measuring the difference between absorbance before and after the radiation ${ }^{26}$.

\section{D-Statistical analysis}

The statistical evaluation of the results [mean, standard deviation (S, D) and standard error of mean (S.E.M.)] were calculated using the scientific calculator. The different variables were compared to each other using the unpaired student test [t-test]. Only $p<0.05$ was regarded as significant $^{27}$.

\section{Results}

Table 1 shows the detail of thirty male persons who were targeted in this study.

Table 2 provides the mean \pm SD of S.MDA and SOD of the four groups. Results reveal that the mean \pm SD of S.MDA concentration is $1.67 \pm 0.21 \mu \mathrm{g} / \mathrm{L}$, and the mean $\pm \mathrm{SD}$ of S.SOD activity is $0.156 \pm 0.03 \mathrm{IU} / \mathrm{L}$, the values exceeded normal ranges (0.5-1.5 and $0.1-0.125$ ) respectively.

Table 1: Details; of subject's number, ages, body mass index, occupational years, marital state, smoking, and chronic illness.

\begin{tabular}{ll} 
Numbers & 30 \\
\hline Ages (Mean \pm SD) & $34.37 \pm 21.92$ \\
$\begin{array}{l}\text { Body mass index (BMI) } \\
\text { (Mean } \pm \text { SD) }\end{array}$ & $23.8 \pm 20.3$ \\
$\begin{array}{l}\text { Occupational years } \\
\text { (Mean } \pm \text { SD) }\end{array}$ & $12.86 \pm 11.5$ \\
$\begin{array}{l}\text { Married (Numbers and \%) } \\
\text { Smokers (Numbers and \%) }\end{array}$ & 27 of $30(90 \%)$ \\
$\begin{array}{l}\text { Chronic illness } 30(43.3 \%) \\
\text { (Numbers and \%) }\end{array}$ & 0 of $30(0.00 \%)$
\end{tabular}

Table 2: The (mean \pm SD) of S.MDA and SOD of the four groups.

\begin{tabular}{llll} 
Parameters & Number & $\begin{array}{l}\text { Values } \\
(\text { Mean } \pm \text { SD) }\end{array}$ & $\begin{array}{l}\text { Normal } \\
\text { ranges }\end{array}$ \\
\hline $\begin{array}{l}\text { S.MDS } \\
(\mu \mathrm{g} / \mathrm{L})\end{array}$ & 30 & $1.67 \pm 1.15$ & $0.5-1.5$ \\
$\begin{array}{l}\text { S.SOD } \\
(\mathrm{IU} / \mathrm{L})\end{array}$ & 30 & $0.156 \pm 0.16$ & $0.1-0.125$
\end{tabular}


Table 3 shows the mean values of S.MDA level and S.SOD activity in four different occupational workers. The mean levels of each S.MDA and S.SOD activity in dyers and asphalt workers group are significantly higher than that of traffic polices and welders group. $P<0.01$. Table 4 provides that the mean $\pm S D$. of S.MDA level is significantly increased according to the age, $\mathrm{P}<0.05$, while there is no any significant difference of S.SOD activity between two groups. Table 5 provides the mean $\pm S D$ of S.MDA level and S.SOD activity. According to the duration of occupational works who worked $\geq 15$ years or < 15years in their jobs, data showed that both S.MDA level and S.SOD activity are significantly increase according to the duration of the occupational works. $\mathrm{P}<0.05$ for S.MDA and $\mathrm{P}<0.01$ for S.SOD activity.

Table 3: Shows the difference among the four groups of their S.MDA and S.SOD activity (Mean \pm SD.)

\begin{tabular}{lllll} 
Parameters & Traffic policemen & Welders & Dyers & Asphalt Workers \\
\hline MDA $(\mu \mathrm{g} / \mathrm{L})$ & $1.17 \pm 1.48$ & $1.47 \pm 1.7$ & $2.65 \pm 1.8$ & $1.539 \pm 1.53$ \\
SOD $(\mathrm{IU} / \mathrm{L})$ & $0.061 \pm 0.22$ & $0.16 \pm 0.17$ & $0.23 \pm 0.19$ & $0.178 \pm 0.19$
\end{tabular}

S.MDA ( $\mu \mathrm{g} / \mathrm{L})$ of dyers $\mathrm{V}$ traffic policemen

$t=4.5 \quad p<0.01$

S.SOD (IU/L) V Traffic policemen

$t=4.5 \quad p<0.01$

S.MDA $(\mu \mathrm{g} / \mathrm{L})$ of asphalt workers $V$ Traffic policemen

$t=1.34 \quad p<0.05$

S.SOD (IU/L) of asphalt worker $V$ Traffic policemen

$t=3.51 \quad p<0.01$

S.MDA $(\mu \mathrm{g} / \mathrm{L})$ of welders $V$ Traffic policemen

S.SOD (IU/L) of dyers $V$ Traffic policemen

$t=0.95 \quad p>0.01 \mathrm{NS}$

$\mathrm{V}$ (versus)

$\mathrm{t}=2.8 \quad \mathrm{p}<0.05$

Table 4: The mean $\pm S D$ of $S$. MDA level and S.SOD activity according to the age (five youngest and five eldest samples)

Parameters The five youngest (Mean \pm SD) The five oldest (Mean \pm SD)

\begin{tabular}{lll}
\hline $\operatorname{MDA}(\mu \mathrm{g} / \mathrm{L})$ & $1.72 \pm 1.75$ & $2.267 \pm 2.14$ \\
$\operatorname{SOD}(\mathrm{IU} / \mathrm{L})$ & $0.19 \pm 0.25$ & $0.136 \pm 0.2$
\end{tabular}

S.MDA of the five older. $V$ the five younger $S . S O D$ of the five older. $V$ the five younger $\mathrm{t}=2.85 \quad \mathrm{P}=0.039$ $\mathrm{V}$ (versus).

Table 5: The mean \pm SD of S.MDA level and S.SOD activity according to the duration of occupational works who worked $\geq 15$ years or $<15$ years in their job.

Parameters Occupational years $\geq 15$ years Occupational years $<15$ years

\begin{tabular}{lll}
\hline $\operatorname{MDA}(\mu \mathrm{g} / \mathrm{L})$ & $1.815 \pm 0.9$ & $1.55 \pm 0.86$ \\
$\mathrm{SOD}(\mathrm{IU} / \mathrm{L})$ & $0.154 \pm 0.07$ & $0.138 \pm 0.1$
\end{tabular}

S.MDA of occupational years $\geq 15$ years $V$ occupational years $<15$ years $\quad t=1.25 \quad P=0.041$ S.SOD of occupational years $\geq 15$ years $V$ occupational years $<15$ years $\quad t=3.825 \quad P<0.01$ $\mathrm{V}$ (versus). 


\section{Discussion}

The mean value of MDA in samples exceeded the normal range (Table 2). The high level of MDA may be due to the lipid peroxidation in a greater rate than the physiological rate. At the same time the levels of SOD are also high compared to the normal range; which is proportional to the increase of MDA. SOD is counteracting the action of MDA which may have increased as a result of oxidative stress and lipid peroxidation. The difference between SOD activity before and after the exposure to light is related to the activation of SOD by light by absorbing energy of light $^{25}$. Table 3 shows that the MAD of traffic policemen and welders are within the normal range, but as for asphalt workers was slightly high, while MAD levels for dyer workers were far exceeded the normal range. This high level is may be due the nature of their working; they are more vulnerable to dye derivative, they also are more exposed to the dye aerosols because of the direct exposure during the indoor dying. This means that they are more exposed to the oxidative stresses comparing to other groups. Serum MAD levels of asphalt factory workers who are directly exposed to emit gases from the asphalt their MAD levels were higher than the normal level. Since traffic polices and welders who are working outdoors, they are less exposed to the direct emitted gases and they inhale more fresh air similar resulted obtained by Armstrong, $D^{7}$. Regarding SOD, traffic polices showed higher level than the control because they are working most of the time exposure to the sun light and it may have negative effects to their defense system. Production of SOD is also due to low level of MDA activity. Welders are nearly normal because of their normal MDA level which is proportional to SOD. Dyer's SOD is also far exceeds the control level due to high level of MDA that induce SOD to produce in high level as part of defense against the high level of oxidative stress and lipid peroxidation. The high level of SOD within the asphalt workers means that they have a greater defense or repair system against any defect in the body. The results caused by exposing workers to the polluted air. As a consequence, exposure to a wide range of air pollutants gives rise to oxidative stress within the lung, and this appears to initiate responses that are particularly dangerous to susceptible members of the occupational workers. One of these responses is the influx of inflammatory cells of the lung ${ }^{26}$.The younger workers have shown high level of MDA (Table 4) but at the same time they have higher level of SOD to produce sufficient efficacy to counteract levels of MDA. The five older ones have high level of MDA but in contrast to the younger ones they showed a lower level of SOD due to their age and physiological condition which may reduce the body ability to produce a quantity of SOD to meet the metabolic action of peroxidation. The results attributed to the results of Akbar Sharifian et $\mathrm{al}^{28}$. they concluded that the correlation between age and total plasma antioxidant capacity was found through a Pearson correlation: $r=0.253, p=0.049$. The results of this study show that the shift work can act as an oxidative stressor. It also shows that the age and the BMI have a negative effect on the oxidative stress. With increase of BMI and age; the antioxidant system becomes more disabled against oxidative stress. Occupational stress increases oxidative stress levels probably as a response to increased generation of reactive oxygen species. A special dietary regimen including antioxidant agents, such as vitamins and minerals, may be beneficial to shift workers. Spending more years in the occupational work increases the oxidative stress and lipid peroxidation. This may have led to the positive correlation between the level of MAD and time spent in that work, Table 5.

Table 5 shows the positive correlation between time spent on the occupational work and the level of MAD, similar results obtained by Frank J Kelly ${ }^{29}$. Spending 
more years that job increases oxidative stress and lipid peroxidation. by age and reducing the level of SOD as a result of aging, generation $\mathrm{H}_{2} \mathrm{O}_{2}$ by mitochondria increased by time and the resulting accumulation damage to macromolecules that causes aging and this is physiologically normal (by aging oxidative stress results in damage to mitochondrial DNA, thus increasing further the production of $\operatorname{ROS}^{4,26,29}$. Ultimately leads to a physiological decline in function, or aging in the persons worked 15 years or less MDA slightly increased but SOD reduced due to poor compensation mechanism.

\section{Conclusion}

Based on findings of the present study it can be concluded that occupational works elevates the release of Superoxide dismutase enzyme, and also increases lipid peroxidation by reactive oxygen species which in turn causes elevation of Malondialdehyde.

\section{References}

1. Sies $H$. Oxidative stress: from basic research to clinical application. Am J Med 1991; 91(3C): 315-85.

2. Cetinkaya A, Kurutas EB, Buyukbese MA, Kantarceken B, Bulbulo E. Levels of Malondialdehyde and Superoxide Dismutase in Subclinical Hyperthyroidism. Clin Chim Acta1999; 196:2-3.

3. Georgeson GD, Szony BJ, Streitman K. Antioxidant enzyme activities are decreased in preterm infants and in neonates born via caesarean section. Eur J Obstet Gynecol Reprod Biol 2002; 103(2):136-9.

4. Miral D, Pawel J. Mechanism of free radicalinduced damage to DNA". Free Radic Res 2012; 46:382-419.

5. Nakai A, Oya A, Kobe H. Changes in maternallipid peroxidation levels and antioxidant enzymatic activities before and after delivery. J Nippon Med Sch 2000; 67(6):434-9.

6. Loeper J, Goy J, Rozensztajn L, Bedu O, Moisson $P$. Lipid peroxidation and protective enzymes during myocardial infarction. Clin Chim Acta 1991; 196(2-3):119-25.

7. Armstrong $\mathrm{D}$, Browne $\mathrm{R}$. The analysis of free radicals, lipid peroxidases, antioxidant enzymes and compounds related to oxidative stress as applied to the clinical chemistry laboratory. Free Radic Diag Med 1994; 366:43-58.

8. Pryor WA, Stanley JP. Letter: A suggested mechanism for the production of malonaldehyde during the autoxidation of polyunsaturated fatty acids. Nonenzymatic production of prostaglandin endoperoxides during autoxidation. J Org Chem 1975; 40 (24): 3615-7.

9. Farmer EE, Davoine C. Reactive electrophile species. Curr Opin Plant Biol 2007; 10(4):380-6.

10. Lef'evre G. Evaluation of lipid peroxidation by measuring thiobarbituric acid reactive substances. Annals de Biologie Clinique (Paris) 1998; 56 (3):305-19

11. Buddi R, Lin B, Atilano SR, Zorapapel NC, Kenney MC, Brown DJ. Evidence of oxidative stress in human corneal diseases. J Histochem Cytochem 2002; 50(5):240-52.

12. Tainer JA, Getzoff ED, Beem KM, Richardson JS, Richardson DC. "Determination and analysis of the 2 A-structure of copper, zinc superoxide dismutase". J Mol Biol 1982; 160(2):181-217.

13. Getzoff ED, Tainer JA, Weiner PK, Kollman PA, Richardson JS , Richardson DC. Electrostatic recognition between superoxide and copper, zinc superoxide dismutase. Nature 1983; 306:287-90.

14. Porntadavity S, Xu Y, Kiningham K, Rangnekar VM, Prachayasitikul V, St Clair DK . TPAactivated transcription of the human MnSOD gene: Role of transcription factors $\mathrm{Sp}-1$ and Egr-1. DNA Cell Biol 2001; 20:473-8.

15. Reaume AG, Elliott JL, Hoffman EK, Kowall NW, Ferrante RJ, Siwek D, et al. Motor neurons inCu/ $\mathrm{Zn}$ superoxide dismutase-deficient mice develop normally but exhibit enhanced cell death after axonal injury. Nat Genet 1996; 3:43-7.

16. Allen $\mathrm{S}$, Badarau $\mathrm{A}$, dennison $\mathrm{C}$. $\mathrm{Cu}(\mathrm{I})$ affinities of the domain 1 and 3 sites in the human metallochaperone for $\mathrm{Cu}, \mathrm{Zn}$-supueroxide dismutase. Biochemistry 2012; 51:1439-48.

17. Williams MD, Van Remmen $H$, Conrad CC, Huang TT, Epstein CJ, Richardson A. Increased oxidative damage is correlated to altered mitochondrial function in heterozygous manganese superoxide dismutase knockout mice. J Biol Chem 1998; 273:510-5.

18. Greenlund L. Superoxide dismutase delays neuronal apoptosis: A role for reactive oxygen species in programmed neuronal death. Neuron 1995; 14:303.

19. Deng L. Amyotrophic lateral sclerosis and structural defects in $\mathrm{Cu}, \mathrm{Zn}$ superoxide dismutase. . Science 1993; 261:986.

20. Venkataraman F. Manganese superoxide dismutaseoverexpression inhibits the growth of androgen-independent prostate cancer cells. Oncogene 2005; 24:77.

21. Navarro-Antolín. Role of peroxynitrite in endothelial damage mediated by Cyclosporine A. Free Radic Biol Med 2007; 42(3):394-403.

22. Jostana A PI, Arun J P, Ajitt V S, Sajay P G. Oxidative stress and antioxidants status of occupational pesticides exposed sprayers of grape gardens of Western Maharashtra (India). 
Biochemstry J 2009; 9:2.

23. Rehncrona S, Smith DS, Akesson B, Westerberg E, Siesjo BK. Peroxidative changes in brain cortical fatty acids and phospholipids as characterized during $\mathrm{Fe}^{2+}$ and ascorbic acid-stimulated lipid peroxidation in vitro. J Neurochem 1980; 34: 1630-8.

24. Gerard MD, Erdelmcier J, Rengard K. Reaction of N-methyl-2-phenilindole with MDA and 4-hydroxy alkenals; analytical application to colorimetric assay of lipid peroxidationChem. Res Tox1997; 60(1):1176-83.

25. McCord JM, Fridovich I. Superoxide dismutase: the first twenty years (1968-1988). Free Radic Biol Med 1988; 5(5-6):363-9.

26. Mikhail FA, Susan P, Ledoux, Glenn L. Mitochondrial DNA and aging. Clinical Science 2004; 107:355-64.

27. Daniel WW. Biostatistics: A foundation for analysis in the health science. 3rd ed. USA: John Wiley and Sons; 1983. P. 123-27.

28. Sharifian A, Farahani S, Pasalar P. Shift workers as an oxidative stressor. JCR 2005; 3:15. 